2. To: (Receiving Organization)

Distribution

5. Proj./Prog./Dept./Div.:

Privatization Infrastructure

8. originator Remarks:

For approval and release. This document describes the technical, programmatic, and management aspects of the Privatization Infrastructure Program that are relevant to privatization support, and it summarizes plans and activities that establish the program's readiness-toproceed.

11. Receiver Remarks: 11A. Design Baseline Document? [] Yes [X] No
3. From: (originating organization)

Tank Waste Retrieval and Disposa]

6. Design Authority/ Design Agent/Cog. Engr.:

R. D. Potter

10. System/Bldg./Facility:

N/A

12. Major Assm. Dwg. No.: $N / A$

13. Permit/Permit Application No.: N/A

14. Required Response Date: $\mathrm{N} / \mathrm{A}$

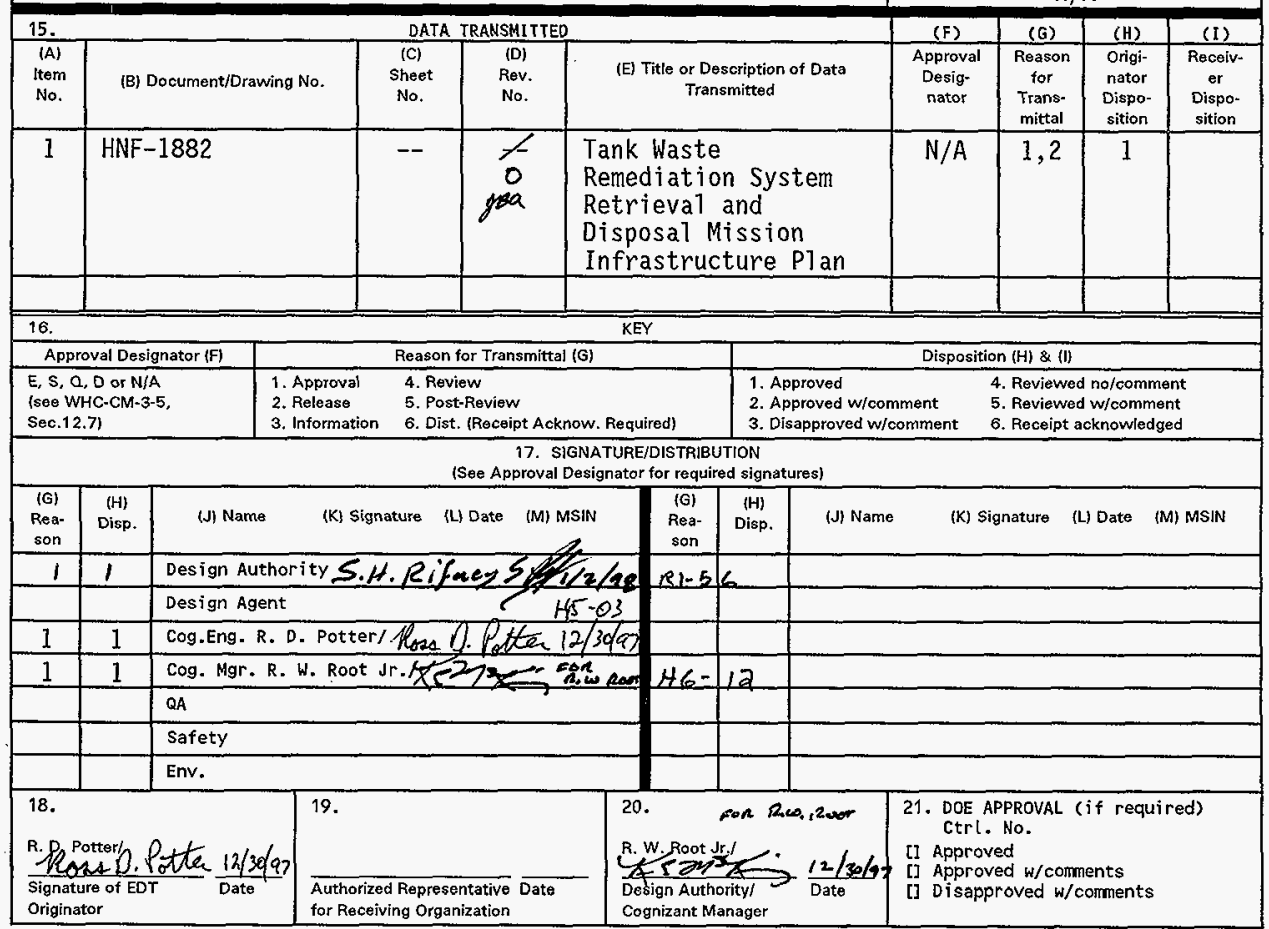


HNF-1882, Rev. 0

\title{
Tank Waste Remediation System Retrieval and Disposal Mission Infrastructure Plan
}

\author{
R.D. Potter \\ Lockheed Martin Hanford Company, Richland, WA 99352 \\ U.S. Department of Energy Contract DE-AC06-96RL13200
}

EDT/ECN: $\quad 622840$

Org Code: 73000

UC: 2030

B\&R Code: EW3130010

Charge Code: D215P

Total Pages: 35

Key Words: TWRS, Disposal Mission

Abstract: This system plan presents the objectives, organization, and management and technical approaches for the Infrastructure Program. This Infrastructure PIan focuses on the Tank Waste Remediation System (TWRS) Project's Retrieval and Disposal Mission.

TRADEMARK DISCLAIMER. Reference herein to any specific commercial product, process, or service by trade name, trademark, manufacturer, or otherwise, does not necessarily constitute or imoly its endorsement, recommendation, or favoring by the United states Government or any agency thereof or its contractors or subcontractors.

Printed in the United States of America. To obtain copies of this document, contact: pocument Control Services, P.0. Box 950, Mailstop 46-08, Richland WA 99352, Phone (50́9) 372-2420; Fax (509) 376-4989.
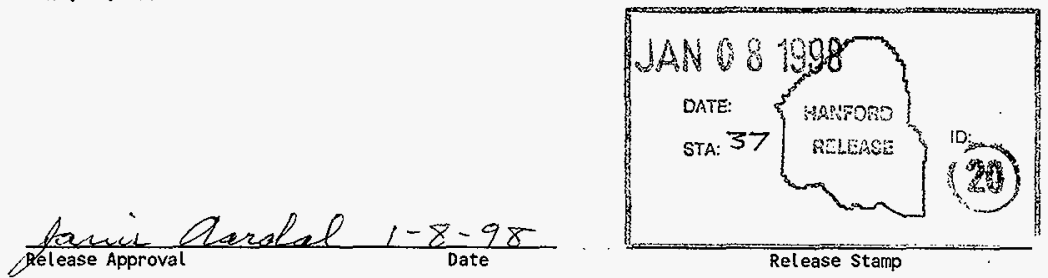

\section{Approved for Public Release}




\section{Tank Waste Remediation System Retrieval and Disposal Mission Infrastructure Plan}

R. W. Root, Jr.

Informatics Corporation

R. D. Potter

MACTEC

Date Published

January 1998

Prepared by Lockheed Martin Hanford Corporation

Richland, Washington

Prepared for the U.S. Department of Energy

(5) Fluor Daniel Hanford, Inc.

P.O. Box 1000

Richland, Washington

Hanford Management and Integration Contractor for the

U.S. Department of Energy under Contract DE-AC-0696-RL-13200 
HNF-1882 Rev 0

This page intentionally left blank. 
Document Title: Tank Waste Remediation System Retrieval and Disposal Mission Infrastructure Plan

Approved by:
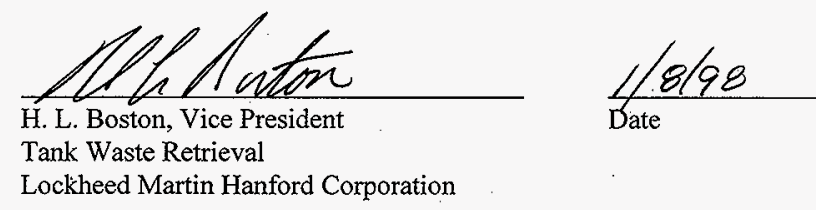
Tank Waste Retrieval Lockheed Martin Hanford Corporation 
HNF-1882 Rev 0

This page intentionally left blank. 


\section{EXECUTIVE SUMMARY}

This system plan presents the objectives, organization, and management and technical approaches for the Infrastructure Program. This Infrastructure Plan focuses on the Tank Waste Remediation System (TWRS) Project's Retrieval and Disposal Mission and is subordinate to HNF-1883, Tank Waste Remediation System Program Plan (Freeman 1998), which should be consulted for additional direction on execution of the Infrastructure Program. The TWRS Retrieval and Disposal Mission includes the activities required to support a two-phased approach to treatment and immobilization of tank waste by private contractors. Phase 1 will be a demonstration phase to assess the effectiveness of private contractor technologies for a small volume of Hanford Site tank wastes, and Phase 2 will be full-scale processing of the remaining wastes.

Before the U.S. Department of Energy (DOE) can authorize private contractors to proceed to the next demonstration phase (Phase 1B), the Project Hanford Management Contract (PHMC) Team must demonstrate that they will be able to provide the necessary support to the private contractors. The PHMC Team must conduct a "readiness to proceed" (RTP) selfassessment of its ability to support the private contractors. The DOE is responsible for reviewing the PHMC assessment, and for conducting an independent RTP evaluation. The status of the PHMC Team's RTP is a key consideration in DOE's decision making about continuing with privatization. 
HNF-1882 Rev 0

Key Infrastructure Program functions that contribute to the Retrieval and Disposal Mission and privatization activities are providing utilities and selected site services to the private contractor facilities that includes the following:

- $\quad$ Electrical power

- Raw, potable, and fire water

- $\quad$ Liquid effluent transfer system

- Site development and roads

- Feed tank turnover - AP-106 and AP-108.

This version of the Infrastructure Plan describes the technical, programmatic, and management aspects of the Infrastructure Program that are relevant to privatization support, and summarizes plans and activities that also help establish the program's RTP. This system plan will be updated periodically to reflect changes to, and evolution of the Infrastructure. Program. Specifically, deactivation and decommissioning/decontamination of Phase 1 infrastructure facilities will be planned during Phase $1 B$. Similarly, decommissioning/ decontamination of the Phase 1 private contractor facilities will be planned during Phase $I B$. 
HNF-1882 Rev 0

\section{CONTENTS}

1.0 INTRODUCTION 1

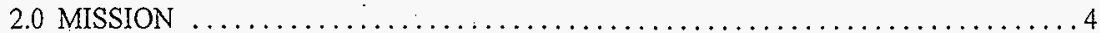

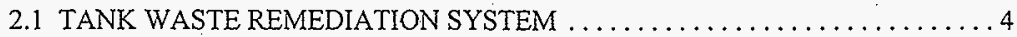

2.2 TANK WASTE RETRIEVAL AND INFRASTRUCTURE $\ldots \ldots \ldots \ldots \ldots \ldots 4$

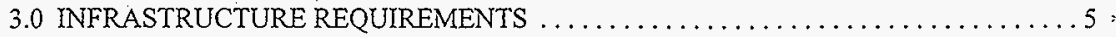

4.0 INFRASTRUCTURE TECHNICAL OBJECTIVES AND APPROACH $\ldots \ldots \ldots \ldots \ldots 6$

5.0 INFRASTRUCTURE PROGRAM ORGANIZATION $\ldots \ldots \ldots \ldots \ldots \ldots \ldots \ldots \ldots$

5.1 TANK WASTE RETRIEVAL DIVISION - PROGRAMS $\ldots \ldots \ldots \ldots \ldots \ldots . . \ldots$

5.2 TANK WASTE RETRIEVAL DIVISION - SUPPORT FUNCTIONS $\ldots \ldots \ldots 10$

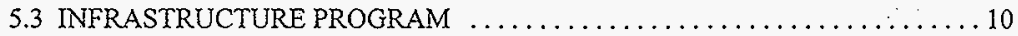

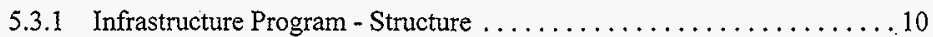

5.3.2 Infrastructure Program - Management and Direction ............ 11

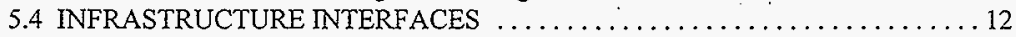

5.4.1 TWR Division - Programs and Support Operations $\ldots \ldots \ldots \ldots \ldots \ldots 12$

5.4 .2 TWRS Project Organizations ......................... 14

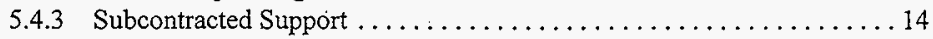

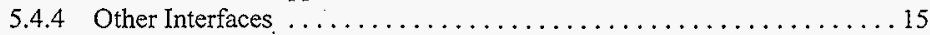

6.0 INFRASTRUCTURE MANAGEMENT APPROACH $\ldots \ldots \ldots \ldots \ldots \ldots \ldots \ldots \ldots \ldots$

7.0 INFRASTRUCTURE PROGRAM WORK BREAKDOWN STRUCTURE, SCHEDULE

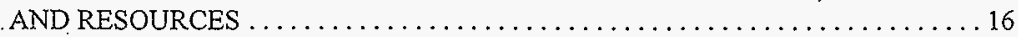

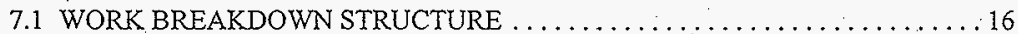

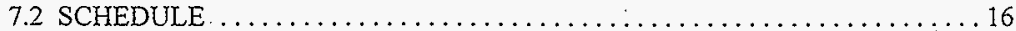

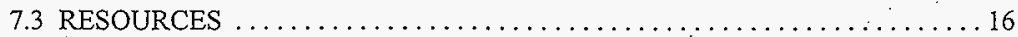

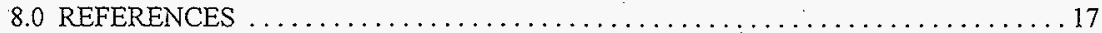

\section{APPENDIX}

GUIDANCE AND REQUIREMENTS TO DELIVERABLES CROSSWALK $\ldots \ldots \ldots \ldots$ A-i 
HNF-1882 Rev 0

\section{LIST OF FIGURES}

1. Readiness to Proceed Document Hierarchy

2. Infrastructure, the Tank Waste Remediation System Project, and the Project Hanford Management Contract .................................... 9

3. Tank Waste Retrieval Organization

\section{LIST OF TERMS}

$\begin{array}{ll}\text { DST } & \text { double-shell tank } \\ \text { Ecology } & \text { Washington State Department of Ecology } \\ \text { EPA } & \text { U.S. Environmental Protection Agency } \\ \text { ES\&H } & \text { environment, safety, and health } \\ \text { FDH } & \text { Fluor Daniel Hanford, Inc. } \\ \text { HSTD } & \text { Hanford Site Baseline Database } \\ \text { HLW } & \text { high-level waste } \\ \text { ICD } & \text { interface control document } \\ \text { LAW } & \text { low-activity waste } \\ \text { LMHC } & \text { Lockheed Martin Hanford Corporation } \\ \text { M\&I } & \text { management and integration } \\ \text { MUST } & \text { miscellaneous underground storage tank } \\ \text { MYWP } & \text { multi-year work plan } \\ \text { PHMC } & \text { Project Hanford Management Contract } \\ \text { SST } & \text { single-shell tank } \\ \text { TRU } & \text { transuranic } \\ \text { TWR } & \text { Tank Waste Retrieval } \\ \text { TWRS } & \text { Tank Waste Remediation System } \\ \text { WBS } & \text { work breakdown structure }\end{array}$




\section{TANK WASTE REMEDIATION SYSTEM RETRIEVAL AND DISPOSAL MISSION INFRASTRUCTURE PLAN}

\subsection{INTRODUCTION}

The Infrastructure Program is one of five major programs (Infrastructure; Development and Demonstration, Waste Feed Delivery, Storage and Disposal, and Tank Closure) within the Tank Waste Retrieval (TWR) Division. The TWR Division is a major element of the Tank Waste Remediation System (TWRS) Project, which is operated by Lockheed Martin Hanford Corporation (LMHC) under DE-AC06-96RL13200, Project Hanford Management Contract (PHMC) (RL 1996). The TWRS Project includes operation and maintenance of the single-shell tanks (SST) and double-shell tanks (DST); retrieval of low-activity waste (LAW) and high-level waste (HLW) from the DSTs, SSTs, and miscellaneous underground storage tanks; delivery of the tank wastes to treatment and immobilization facilities; interim storage and disposal of immobilized LAW; temporary storage and final disposition of immobilized HLW; and safe closure of the DSTs, SSTs, miscellaneous underground storage tanks, and tank farm facilities.

The TWR Division is responsible for the programmatic management of the Waste Retrieval and Disposal Mission, which includes delivery, storage, and disposal, and tank farm closure under the TWRS Project. Within the TWR Division, the scope of the Infrastructure Program is to provide site development and utilities to the private contractors.

This document was prepared to support the Infrastructure Program's readiness to support the delivering of tank waste feed in accordance with established schedules and specifications. This document is one of the tools used to develop and control the mission work as depicted in Figure 1 . The primary purpose of this Infrastructure Plan is to provide contributing managers and staff with the minimum direction and guidance necessary to achieve Infrastructure's goals and objectives. These goals and objectives, and their accomplishment, must be consistent with higher order missions and charters, management policies and directives, and business and contractual responsibilities. Consequently, this Infrastructure Plan integrates relevant mission, strategic, and business planning requirements for the waste retrieval and storage mission with the specific work scope and project activities to be accomplished in support of infrastructure.

This Infrastructure Plan summarizes the bases for the work performed by the Infrastructure Program, describes organizational relationships and interfaces, and establishes Infrastructure work practices. These practices are in accordance with life-cycle asset management concepts and address the following areas: managing and controlling technical and Programmatic Baselines; applying systems engineering and configuration management methods; 
Figure 1. Readiness to Proceed Document Hierarchy.

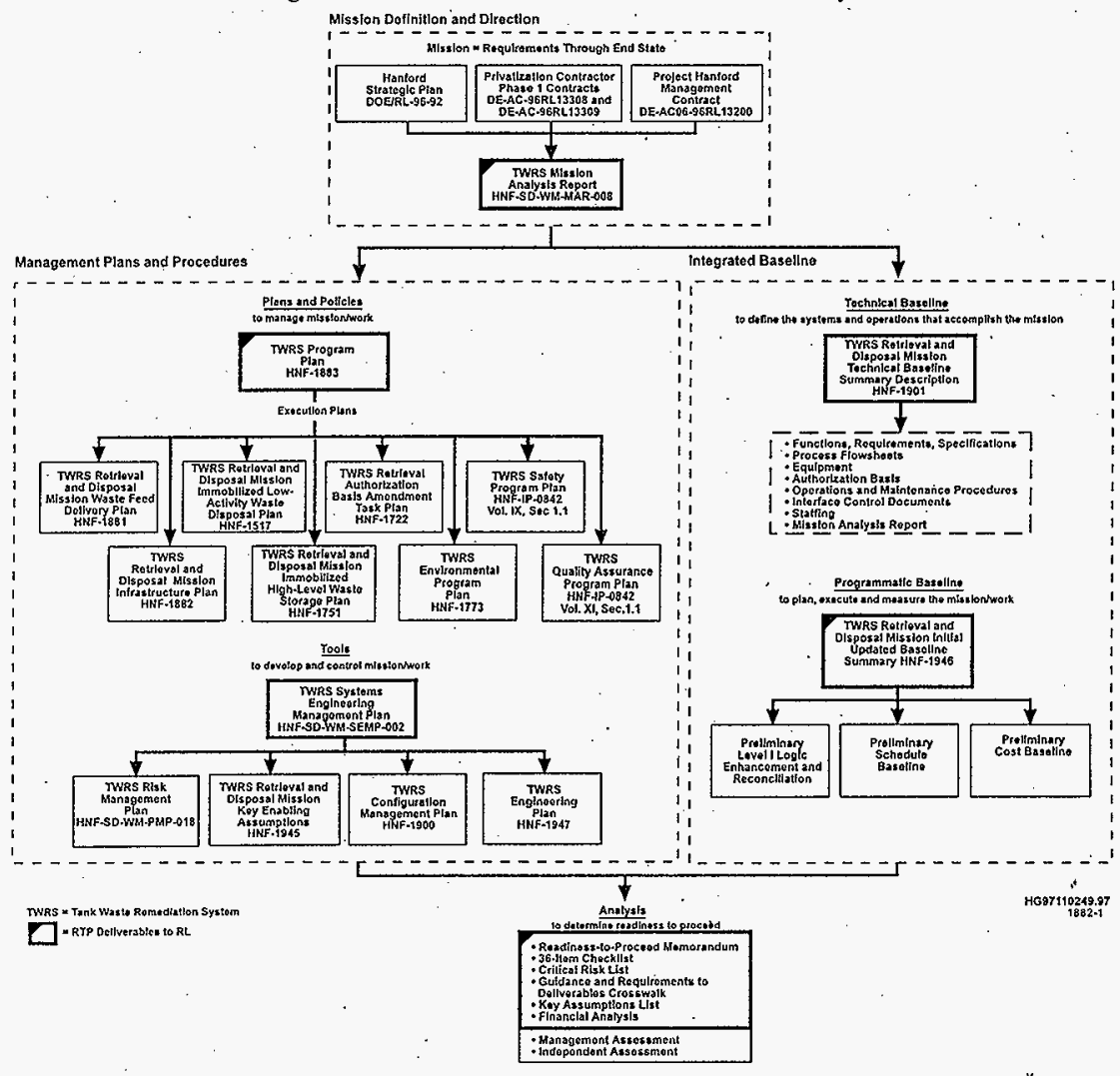


acquiring and sustaining human and other resources for work performance; assuring health, safety, and environmental compliance; achieving quality assurance, self-assessment, and startup readiness; and promoting stakeholder interests throughiopen communication and economic transition. follows.

After this Introduction, this Infrastructure Plan is organized into seven sections, as

- Mission. This section summarizes the missions, charters, and objectives that are relevant : to infrastructure. These mission needs derive primarily from Hanford Site strategies, Waste Retrieval and Storage Program, and they provide the general bases and rationale for infrastructure work.

- Infrastructure Requirements. This section briefly identifies the requirements that the infrastructure systems, processes, and projects must satisfy and includes references to primary source documents where the requirements are established.

- Infrastructure Technical Objectives and Approach. This section summarizes the technical objectives that Infrastructure must achieve and the overall means by which these objectives will be accomplished.

- Infrastruicture Organization. This section presents the Infrastructure organization and its relationship to functional organizations, projects, and other supporting entities within the TWRS Project. It also describes important interfaces between Infrastructure and other parties that are external to the IWRS Project.

- Infrastructure Management Approach: This section describes the management activities Infrastructure will apply to accomplish its program objectives.

- Infrastructure Program Work Breakdown Structure, Schedule and Resources. This section summarizes how infrastructure work is performed in accordance with the TWRS work breakdown structure (WBS), which forms the basis for structuring work for the Multi-Year Work Plan (MYWP). This section also provides a summary schedule of the planned infrastructure work activities, and a summary estimate of the resources necessary to support the currently planned level of infrastructure work.

- References. Provides a listing of the references cited in this document. 


\subsection{MISSION}

The basis for infrastructure work derive from the mission needs and requirements for the Hanford Site and TWRS Project, and TWRS Retrieval and Disposal Mission. This section of the Infrastructure Plan describes the mission needs that are relevant to the work that Infrastructure is expected to undertake. These mission needs provide the foundation for defining infrastructure work.

\subsection{TANK WASTE REMEDIATION SYSTEM}

The long-term mission for Waste Retrieval and Disposal is to retrieve current and future tank wastes, separate the wastes into LAW and HLW, immobilize the waste, store and dispose of immobilized LAW at the Hanford Site, temporarily store immobilized HLW in an offsite repository, manage certain other wastes associated with immobilization (e.g., cesium/strontium), and close the tank farms prior to turnover for final environmental remediation. The full range of TWRS projects and objectives are discussed in more detail in HNF-1883, Tank Waste Remediation System Program Plan (Freeman 1998) and in HNF-SD-WM-MAR-008, Tank Waste Remediation System Mission Analysis Report (Acree 1998). Although not all TWRS Project goals and objectives are directly pertinent to infrastructure, activities within the Infrastructure Program must be consistent with the TWRS mission.

\subsection{TANK WASTE RETRIEVAL AND INFRASTRUCTURE}

The TWR Division chapter, as discussed in HNF-IP-0842, Tank Waste Remediation System Administration, Volume 1, "Administration," Section 3.28, "Tank Waste Disposal Charter" (LMHC 1997), is to conduct business to achieve the common goals of TWRS, as follows.

"Achieve real cleanup progress by planning the processes and activities, and designing and constructing the facilities or equipment that: (1) retrieves waste from the single- and double-shell tanks, (2) separates tank waste into high-level and low-activity fractions and delivers feed to privately-owned and operated immobilization facilities, (3) stores and disposes immobilized waste, and (4) closes the tank farms." -

"Maintain management and financial control over the integrated technical, cost, and schedule baselines; meet baseline commitments and milestones."

"Add stability to the local economy through an acquisition strategy that uses the best qualified, most competitive, and timely outside resources to provide technical support, products, and systems that augment the onsite capabilities." 


\section{HNF-1882 Rev 0}

The mission of the Infrastructure Program is to provide utilities and selected site services to the private contractor facilities that include the following:

- Electrical power

- Raw, potable, and fire water

- Liquid effluent transfer systems

- Site development and roạds

- Feed tank turnover AP-106 and AP-108

- Facilitate radioactive solid waste transport and disposal requirements definition and resolution.

Finally, HNF-SP-1230, Tank Waste Remediation System Fiscal Year 1998 Multi-Year Work Plan WBS $1 . i$ (TWRS MYWP) (Lenseigne 1997) provides further elaboration as follows:

"The Privatization Phase 1 infrastructures project provides the required facilities and systems that assures the waste disposal private contractors are integrated into the Hanford Site infrastructure. This project also provides funding that covers the cost for electricity and water used by the private contractors. The project also provides funds for $\mathrm{PHMC}$ costs associated with the $\mathrm{PHMC}$ receiving liquid effluents, and radioactive solid waste from the private contractors. Phase 1 Infrastructure provides the incremental funding required by the PHMC organizations that operate and maintain the infrastructure systems added to accommodate the private contractor."

As part of the Phase 1 contract with the private contractor, the PHMC will provide funding to train potential operator work force.

\subsection{INFRASTRUCTURE REQUIREMENTS}

Numerous requirements apply to the infrastructure systems, processes, and projects. These requirements and the chosen methods for their implementation are the primary basis for the WBS, schedules, tasks, and budgets associated with infrastructure. External requirements derive from various sources, including promulgated laws and regulations (e.g., U.S. Environmental Protection Agency [EPA], Washington State Department of Ecology [Ecology]), orders and directives (e.g., U.S. Department of Energy), implementation procedures (e.g., safety authorization bases), professional organizations and publications (e.g., American National Standards Institute), and contractual documents (e.g., PHMC [RL 1996]). 
An overview of the various waste retrieval and storage technical requirements is provided in HNF-1883 (Freeman 1998). Technical requirements for the Infrastructure Program will be captured in the Hanford Site Technical Baseline Database (HSTD) and HNF-1901, Tank Waste Remediation System Retrieval and Disposal Mission Technical Baseline Summary Description (Treat et al. 1998). These requirements are derived from the DOE specification and from ICDs. HNF-1947, TWRS Systems Engineering Plan (Rifaey 1998), will be the basis for an Infrastructure systems engineering process that will allocate functions to requirements. Most infrastructure activities during Phase 1 are affected or defined by technical requirements related to providing the following services to private contractor facilities:

- Electrical power

- Raw, potable, and fire water

- Liquid effluent transfer system

- Site development and roads

- Feed tank turnover AP-106 and AP-108

- Facilitate radioactive solid waste transportation and disposal requirements definition and . resolution.

Programmatic requirements are primarily addressed in the implementing plans and procedures established by LMHC for the TWRS Project in HNF-IP-0842 (LMHC 1997). Most infrastructure activities are affected or defined by programmatic requirements related to: baseline management (including the Programmatic Baseline and the Technical Baseline); Systems Engineering management (including configuration management, risk management, alternatives management, and interface management); environmental, safety and health (ES\&H), Quality Assurance; acquisition management; performance assurance; stakeholder affairs; and business management. These programmatic requirements pertinent to waste retrieval and disposal and infrastructure are discussed in HNF-1883 (Freeman 1998).

\subsection{INFRASTRUCTURE TECHNICAL OBJECTIVES AND APPROACH}

The primary goal of the Infrastructure Program is to accomplish the infrastructure mission needs previously described in Section 2.0 of this Infrastructure Plan. There are various over-arching technical objectives that infrastructure activities must satisfy in order to achieve the Waste Retrieval and Delivery Mission needs. 
The Infrastructure Program is responsible for meeting the following Phase 1 objectives:

- Complete Phase 1 site characterization

- Complete construction of water systems supply to private contractor facilities

- Complete effluent transfer systems to service private contractor facilities

- Complete construction of electrical system supply to private contractor facilities

- Facilitate radioactive solid waste transportation and disposal requirements definition and resolution

- Complete site development and roads of Phase 1 site

- Issue Revision 2 Master Site Plan for Phase 1

- Feed tank turnover - AP-106 and AP-108

- Define training requirements for operators to be tranisferred to the private contractors and provide a plan to meet these requirements.

The Infrastructure Program mission includes resolving physical interfaces with the private contractors and assisting with an efficient and effective transition between Phases 1 and 2. The planning for Phase 1 Infrastructure deactivation/decontamination/decommissioning and decontamination/decommissioning of private contractor's Phase 1 facilities will be planned during Phase 1B. The objectives outlined above will be accomplished in ways that will best support this transition. Other Phase 2 objectives that support both the option of privatizing infrastructure activities and the option of continuing government contractor operation of infrastructure include:

- Complete construction of Phase 2 water system

- Complete construction of Phase 2 effluent transfer

- Complete construction of Phase 2 electrical system

- Complete. construction of Phase 2 site development and roads. 


\subsection{INFRASTRUCTURE PROGRAM ORGANIZATION}

This section describes the Infrastructure Program organization that performs infrastructure work, and discusses the overall roles and responsibilities of key projects and organizations that support the Infrastructure Program. This section also identifies important interfaces with other programs, functional organizations, and projects.

The PHMC is the primary basis for accomplishing Management and Integration to be performed at the Hanford Site, and establishes the basic PHMC Team relationships and work scopes. Figure 1 depicts where, within the overall PHMC Team, the TWR Division and Infrastructure Program is located. The overall relationship of the Infrastructure Program organization to the Tank Waste Remediation System Project is described in HNF-1883, Tank Waste Remediation System Program Plan (Freeman 1998).

\subsection{TANK WASTE RETRIEVAL DIVISION - PROGRAMS}

The TWR Division organization consists of five principal program areas, which receive administrative and technical assistance from several support operations (Figure 2).

In addition to the Infrastructure Program, the principal responsibilities of each program include the following.

- Tank Closure Program. Provide data to support decisions on tank farm closure; specify criteria for turnover of tank systems for closure; and close the SSTs, DSTs, miscellaneous underground storage tanks, and associated ancillary tank system equipment.

- Immobilized Waste Program. Receive, store, and dispose immobilized LAW from the private contractors; receive, store, and prepare immobilized HLW from the private contractors for geologic repository acceptance; manage the strontium, transuranic (TRU), and other separated tank waste returned from the private contractors; and provide for the final disposition of packaged cesium product.

- Development and Demonstration Program. Deploy advanced technologies for the retrieval of waste from the SSTs (Hanford Tanks Initiative); integrate vadose zone program activities; and establish retrieval performance objectives that will form the basis for tank closure criteria.

- Waste Feed Delivery Program. Deliver waste feed to the privately owned and operated waste immobilization facilities within specification and on schedule. Waste Feed Delivery's goal is to retrieve waste from DSTs, SSTs, and miscellaneous underground storage tanks, condition the waste as necessary, and transfer it as feed to private contractor plants for immobilization. 
Figure 2. Infrastructure, the Tank Waste Remediation System Project, and the Project Hanford Management Contract.

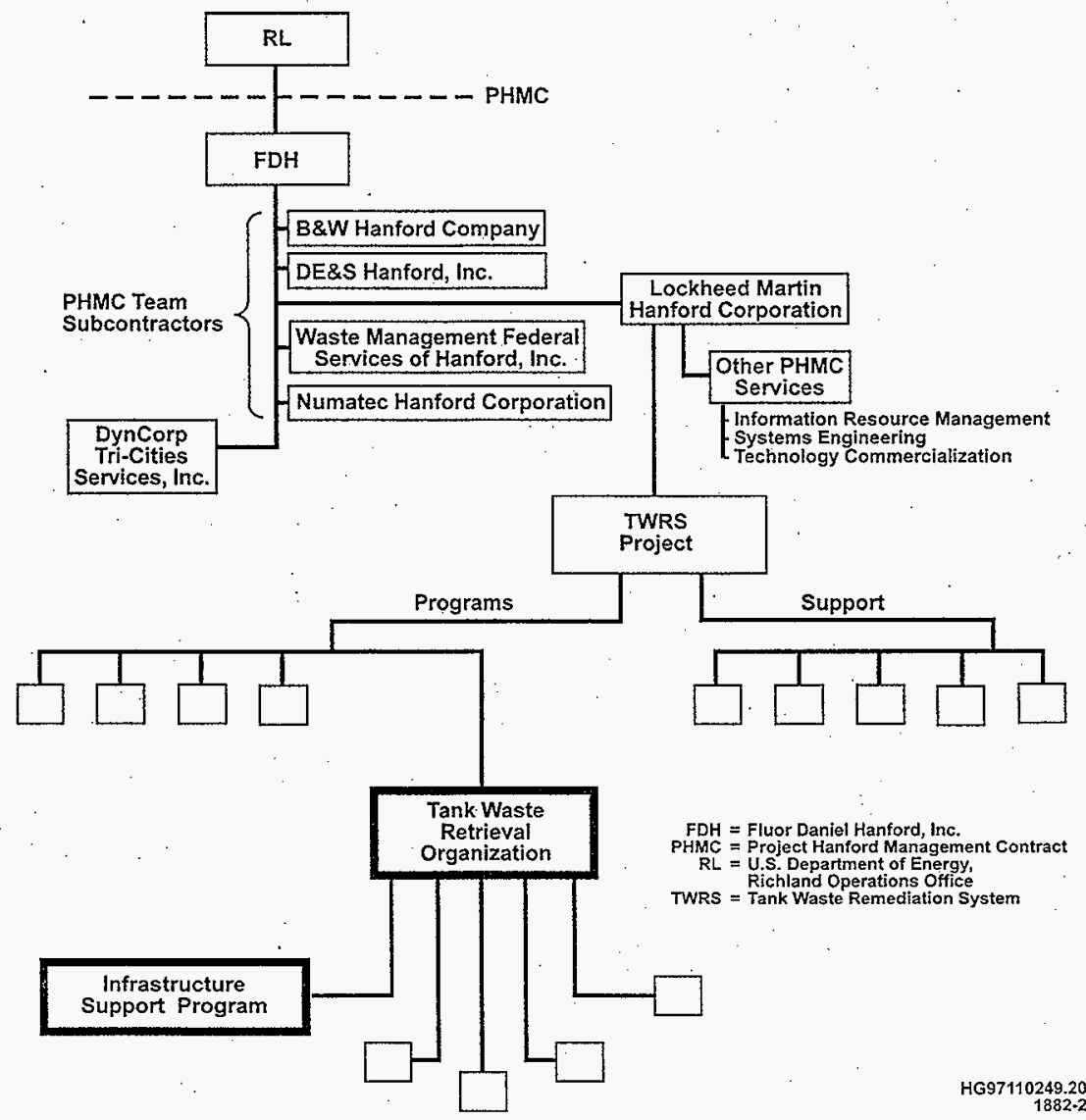

The five TWR Division programs are interrelated and highly dependent on the successful completion of each of their respective missions. Coordination and interfacing ensure consistency of planning efforts, concurrence on overlapping or dependent technical issues and resolutions, integration of turnover efforts as different project phases begin and end, and sharing of staff as needed to balance temporary work overloads. 


\subsection{TANK WASTE RETRIEVAL DIVISION - SUPPORT FUNCTIONS}

The TWR: Division includes program support operations provide planning, management, and performance support to the Infrastructure Program. These TWR Division support operations include: Project Implementation; Planning and Integration; Business Management; Systems Engineering; and Quality Assurance. The scope and responsibilities of the TWR Division supporting operations to the Infrastructure Program are described in HNF-1883 (Freeman 1998) and Sections 5.3 and 5.4 of this plan.

The Infrastructure Program relies on TWRS Project functional organizations and projects for technical support. These organization are matrixed to the TWR Division and its programs. Organizational contacts representing each matrixed organization are assigned to the TWR. Division Director and/or program manager to facilitate communication, technical support, and resource assignments. The organizational contacts are responsible for facilitating integration across the different functional organizations and projects that support the program, as well as representing the interests of their respective functional organization or project. The matrixed organizations and projects include Characterization; Nuclear Safety and Licensing; Quality Assurance; Systems Engineering; ES\&H; Tank Farm Operations; Maintenance; Equipment Engineering; and TWRS Construction Projects. The scope and responsibilities of this technical support is described in HNF-1883 (Freeman 1998).

\subsection{INFRASTRUCTURE PROGRAM}

\subsubsection{Infrastructure Program - Structure}

The Infrastructure Program (and its supporting functions) is structured to accomplish the objectives presented in Section 4.0 of this system plan.

Infrastructure Program organization is structured into two sections: System Definition and W-519. Each of these sections represents a functional performance area, with primary responsibilities as follows.

- System Definition. Responsible for: (1) defining requirements and providing pre-conceptual definition for executable projects, and providing the necessary systems engineering documents; (2) resolving interface issues and establishing interface requirements for solid and liquid waste; (3) conducting integrity assessment programs for tanks to be turned over to the private contractor; (4) establishing turnover interface control drawings and operating procedures for the tanks to be turned over to the private contractors; and (5) defining training requirements for operators to be transferred to the private contractor operations and prepare a plan to meet the agreed scope. 


\section{HNF-1882 Rev 0}

- W-519. Responsible directly to the TWRS Projects group for implementing the engineering and construction requirements and providing the completed utilities and site development.

\subsubsection{Infrastructure Program - Management and Direction}

The Infrastructure Program is directed by the Infrastructure Program Manager whose duties and responsibilities are as follows.

Infrastructure Program Manager. The Infrastructure Program Manager is responsible for overall performance of the Infrastructure Program. Duties include the following:

- Establishing program priorities in accordance with the TWRS Retrieval and Disposal Mission and objectives

- Integrating annual Infrastructure program and tàsk plans and resource forecasts with TWR Division planning efforts

- $\quad$ Ensuring Infrastructure Program baselines remain consistent with the established Programmatic Baselines

- Imposing corrective actions and recovery plans as necessary to maintain timely and effective performance of infrastructure work

- Developing annual program plans, assembling annual task plans, compiling resource forecasts, and preparing other programmatic level documents for planning Infrastructure Program activities

- Acting as the lead for receiving and disseminating program budget and schedule reports

- Monitoring and ensuring Infrastructure Program performance remains consistent with established program baselines.

Program Facilitators. As noted in Section 5.1.2 of this Infrastructure Plan, technical support is provided to the Infrastructure Program through support projects and functional organizations. To facilitate managing the work, the Infrastructure Program managers and staff will access Program Facilitators; personnel working for the TWR Division or Infrastructure Program and assigned on a part-time basis the lead responsibility for interfacing with the supporting functions. 
The Program Facilitators are responsible for communicating, coordinating, facilitating, and monitoring the performance of work involving waste retrieval and storage support functions. Chief duties of the Program Facilitators include the following:

- Establishing effective communications with the program manager, project point of contract (e.g., W-519 Project Manager), or functional organization point of contact (e.g., Nuclear Safety, Characterization)

- Evaluating periodic reviews and reports to assess the adequacy of the work performed by : the supporting function .

- Identifying and bringing appropriate attention to successes and deficiencies

- Taking the lead on implementing improvements in operations and project support.

As indicated in Figure 3, the preferred practice will be for the Infrastructure Program to work directly with the supporting functions to accomplish infrastructure work. While the primary role of the Program Facilitators is to facilitate these work interfaces, coordination and acquisition of support may periodically require involvement of other TWR Division managers. These and other interface issues are discussed in the following section of this Infrastructure Plan.

\subsection{INFRASTRUCTURE INTERFACES}

The Infrastructure Program must interact with and rely on other organizations and entities. The principal Infrastructure Plan interfaces are addressed below.

\subsubsection{TWR Division - Programs and Support Operations}

In general, communication and coordination within the TWR Division will occur directly between staff. Program Facilitators will help identify and resolve project implementation, systems engineering, and quality assurance issues between organizations. Operations and programmatic assistance will be obtained from the TWR Division support organizations identified in Section 5.1.2. Specific interfaces with and assistance to the Infrastructure Program include the following.

- Project Implementation. Coordination and interface with the Infrastructure Program will primarily involve facilitation of work on design and construction (large capital) projects. The Infrastructure Program will identify the key engineering safety, permitting, operations, and construction requirements that must be satisfied in association with projects Project Implementation will take the lead on arranging for the required organization support (e.g., Tank Farm Operations, TWRS Construction Projects). 
Figure 3. Tank Waste Retrieval Organization.
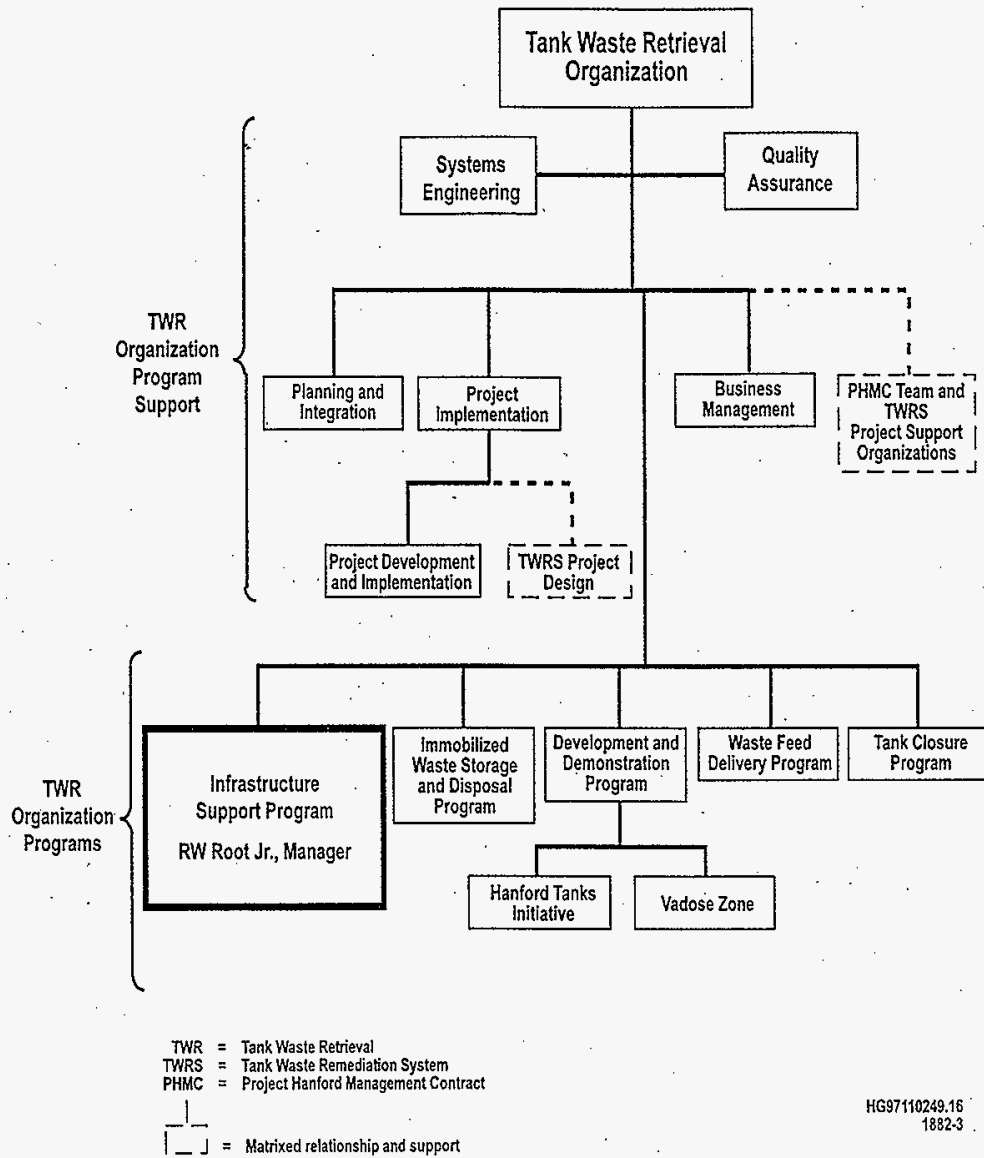

HG97110249.16 1882.3 .

- Planning and Integration. Coordination and interface with the Infrastructure Program will primarily involve periodic status checking to ensure consistency among infrastructure and other TWRS Retrieval and Disposal Mission planning efforts. The Infrastructure Program must coordinate with Planning and Integration on issues involving the private contractors (e.g., interface control documents [ICDs]) and contract support 
from the PHMC Team members (e.g., Waste Management Hanford, DynCorp Tri-Cities Services, Inc.), baselines, establishing and initiating tasks (including resource acquisition), and monitoring for and correcting variances from baseline budgets and schedules.

- Systems Engineering. Coordination and interface with the Infrastructure Program ensure that: the physical architecture and supporting documents meet established systems engineering requirements; risk management procedures are properly implemented; the means for achieving "product-dependent" interfaces are well described; and configuration : management methods are applied to control changes to systems, structures, and components and supporting Technical Baseline documents.

- Quality Assurance. Coordination and interface between Quality Assurance and the Infrastructure Program will ensure that requirements from higher order quality assurance documents are adequately incorporated into infrastructure work. Additional Quality Assurance involvement will be directed at ensuring that personnel training and qualifications are adequate, and that independent audits and self-assessment activities are conducted to continuously improve performance. The existing TWRS corrective action tracking system will be utilized as appropriate. Implementation of Quality Assurance is discussed in more detail in HNF, 1883, Tank Waste Remediation System Program Plan. Project W-519 will prepare a project specific Quality Assurance Plan in FY 1998.

\subsubsection{TWRS Project Organizations}

Program Facilitators (one for each functional organization and major project) will be identified within the Infrastructure Program, and organizational contacts will be identified within each functional organization and major project. These individuals are responsible to help oversee and facilitate the identification and resolution of issues such as unreviewed safety questions (USQ) and Authorization Basis issues, including issues that have been elevated by staff. The Program Facilitators will communicate the breadth of Infrastructure Program requirements, enabling assumptions, risks, and other matters pertinent to infrastructure accomplishment to the designated organizational contacts. The Program Facilitators and organizational contacts will attempt to resolve differences between the objectives of infrastructure and the supporting functional organizations or programs. The Infrastructure Program Manager acts as an overall coordinator and interface lead for developing infrastructure project requirements.

\subsubsection{Subcontracted Support}

Subcontracted support to the Infrastructure Program will be required for workload - balancing, specialty expertise, and economic diversification. Interfacing between the Infrastructure Program and a subcontractor will normally occur directly between staff, particularly for day-to-day communication and coordination. The primary PHMC Team subcontractors from which the Infrastructure Program will obtain services include Waste 
Management Hanford, Fluor Daniel Northwest Engineering, Numatec Engineering, and DynCorp Tri-Cities Services, Inc. Contract related negotiations and paperwork must be approved by the LMHC Contracts Division. An Acquisition Plan will be prepared for the Infrastructure design, construct, and startup activities. It is intended that agreements such as Memorandums of Understanding will be prepared for utilities and waste treatment services. Training programs will be established as required in fiscal year (FY) 1998 and FY 1999.

\subsubsection{Other Interfaces}

In general, the remaining interfaces with the Infrastructure Program are indirect and in support of other organizations with the responsibility for direct interaction. These remaining interfaces include the U.S. Department of Energy, Fluor Daniel Hanford, Inc. (FDH), the Waste Integration Team, the private contractors, regulatory and other oversight agencies, stakeholders, and the general public. These interfaces are described in more detail in HNF-1883 (Freeman 1998).

\subsection{INFRASTRUCTURE MANAGEMENT APPROACH}

The Infrastructure Program implements numerous management systems and activities to ensure that Infrastructure planning and implementation satisfy higher tier directives and guidance. These management systems and activities derive from or are encompassed in practices . and procedures established for waste retrieval and storage (e.g., Closure, Immobilized Waste). The management approach and specific systems, tools, plans, reports, and other mechanisms that the Infrastructure Program will rely on to conduct its business is described in HNF-1883 (Freeman 1998). These include, but are not limited to, scope, schedule, cost, technical baselines, configuration management, change control practices, risk, alternatives, interface management, acquisition management, and performance monitoring.

A key management tool is peer and independent reviews of selected Infrastructure technical products. The applicable Infrastructure activity maintains the plan for independent reviews. Audits and self assessments are discussed further in HNF-1883, Tank Waste Remediation System Program Plan (Freeman 1998). 


\subsection{INFRASTRUCTURE PROGRAM WORK BREAKDOWN STRUCTURE, SCHEDULE AND RESOURCES}

\subsection{WORK BREAKDOWN STRUCTURE}

A WBS has been established for planning, execution, and control of work under the Waste Retrieval and Storage Mission, including infrastructure work. The WBS is the primary means of organizing infrastructure tasks and activities, and forms the basis for structuring work in the TWRS MYWP (Leseigne 1997). The WBS represents the scope of work which, when sequenced in Level 1 logics (FDH 1998), enables the work to be estimated, scheduled, budgeted, performed, and managed.

The infrastructure activities are broken into discrete packages for performance tracking and reporting. This work is detailed in activity data sheets, which are held as backup to the TWRS MYWP (Lenseigne 1997) and are available from the Infrastructure Program files. The status of each active element is monitored regularly to determine if the planned work is being accomplished on schedule and within budget. Adjustments are made as program and project requirements demand.

\subsection{SCHEDULE}

The Waste Retrieval and Storage Mission baseline schedule (including infrastructure work) is shown in HNF-SP-1230 and HNF-1946, Tank Waste Remediation System Retrieved Disposal Mission Initial Updated Baseline Summary (Lenseigne 1997). Separate detail schedules have been prepared, consistent with the WBS and the current baseline schedule, for tasks needed to successfully complete the infrastructure work scope. Each detail schedule identifies the logic ties and interfaces necessary to coordinate its completion with the other elements of the Infrastructure Program baseline schedule. These interfaces and dependencies are described in Technical Basis Reports, task plans, and detailed logics. Changes to the infrastructure schedule baseline will be processed consistent with configuration management and change control process described in-HNF-MP 013, Project Hanford Management Contract Configuration Management Plan (Brobst 1997) and HNF-1883, Tank Waste Remediation System Program Plan. The infrastructure logics have been reviewed and are consistent with Conceptual Design Report schedules, feed delivery schedules, private contractor schedules and appropriate ICDs.

\subsection{RESOURCES}

The main elements of the cost estimate correspond to the work activities of the WBS. A detailed breakdown of the Infrastructure Program cost estimate is provided in HNF-SP-1230 (Lenseigne 1997) and summarized in HNF-1946, Tank Waste Remediation System Retrieval and Disposal Mission Initial Updated Baseline Summary (Treat et al. 1998). 
The level and types of human resources needed to accomplish Infrastructure Program activities have been projected in order to anticipate and manage variances in overall staffing, technical and management expertise, and administrative support. Periodically, the Infrastructure Program will require support from individuals and companies who offer unique or supplementary services. The Infrastructure Program will decide which type of resources (e.g., internal staffing, subcontract) are most appropriate based on subcontracting and business practices established for the TWRS Project.

\subsection{REFERENCES}

\section{Database}

HSTD, n.d., Hanford Site Technical Baseline Database, database maintained by Lockheed Martin Hanford Corporation for Fluor Daniel Hanford, Inc., Richland, Washington.

\section{Logic Diagrams}

FDH, 1998, Logic Diagrams, prepared by Lockheed Martin Hanford Corporation for Fluor Daniel Hanford, Inc., Richland, Washington.

- $\quad$ H-2-823148, TWRS Retrieval Level I Logic Immobilized Waste (ILAW)

- H-2-829149, TWRS Retrieval Level 1 Logic Immobilized Waste (IHLW)

- $\quad$ H-2-829150, TWRS Retrieval Level 1 Logic Infrastructure Phase 1 Privatization Support

- H-2-892151, TWRS Retrieval Level 1 Logic Waste Feed Delivery LAW Ist Feed Batches Tank 24I-AN-105

- $\quad$ H-2-829152, TWRS Retrieval.Level I Logic Waste Feed Delivery LAW 2nd Feed Batches Tank $241-A N-104$

- . H-2-829153, TWRS Retrieval Level 1 Logic. Waste Feed Delivery LAW 3rd Feed Batches Tank 24I-AW-101

- H-2-829154, TWRS Retrieval Level 1 Logic Waste Feed Delivery LAW 4th Feed Batches Tank 241-AN-103

- H-2-829155, TWRS Retrieval Level 1 Logic Waste Feed Delivery LAW 5th Feed Batches Tanks 241-AP-101\& 241-AW-104

- H-2-829156, TWRS Retrieval Level 1 Logic Waste Feed Delivery LAW 6th Feed Batches Tank 241-AY-101

- $\quad$ H-2-829157, TWRS Retrieval Level 1 Logic Waste Feed Delivery LAW 7th \& 8th Feed Batches Tank 241-AN-107

- H-2-829158, TWRS Retrieval Level I Logic Waste Feed Delivery LAW 9th Feed Batches Tank $241-A N-102$

- $\quad$ H-2-829159, TWRS Retrieval Level I Logic Waste Feed Delivery LAW 1Oth Feed Batches Tank $241-A N-106$

- H-2-829160, TWRS Retrieval Level I Logic Waste Feed Delivery LAW 11th Feed Batches Tank 241-SY-101 
- H-2-829161, TWRS Retrieval Level 1 Logic Waste Feed Delivery LAW 12th Feed Batches Tank 241-SY-103

- H-2-829162, TWRS,Retrieval Level 1 Logic Waste Feed Delivery HLW 1st \& 2nd Feed Batches First Tank, 241-AZ-101

- H-2-829163, TWRS Retrieval Level 1 Logic Waste Feed Delivery HLW 3rd \& 4th Feed Batches Second Tank, 241-AZ-102

- H-2-829164, TWRS Retrieval Level I Logic Waste Feed Delivery HLW 5th - 9th Feed Batches Third Tank, 24l-AY-102

- H-2-829165, TWRS Retrieval Level 1 Logic Waste Feed Delivery HLW IOth - 12th Feed : Batches Fourth Tank, 241-C-104

- $\quad$ H-2-829166, TWRS Level O.Logic (2 Sheets)

\section{Documents}

Acree, C. D., Jr., 1998, Tank Waste Remediation System Mission Analysis Report, HNF-SD-WM-MAR-008, Rev. 2, prepared by Lockheed Martin Hanford Corporation for Fluor Daniel Hanford, Inc., Richland, Washington.

Freeman, D. V., 1998, Tank Waste Remediation System Program Plan, HNF-1883, Rev. 0, prepared by Lockheed Martin Hanford Corporation for Fluor Daniel Hanford, Inc., Richland, Washington.

Lenseigne, D. L., 1997, Tank Waste Remediation System Fiscal Year 1.998 Multi-Year Work Plan WBS 1.1, HNF-SP-1230, Rev. 0, prepared by Lockheed Martin Hanford Corporation for Fluor Daniel Hanford, Inc., Richland, Washington.

LMHC, 1997, TWRS Administration, HNF-IP-0842, Fluor Daniel Hanford, Inc., Richland, Washington.

Rifaey, S. H., 1998, Tank Waste Remediation System Engineering Plan, HNF-1947, Rev. 0, prepared by Lockheed Martin Hanford Corporation for Fluor Daniel Hanford, Inc., Richland, Washington.

Treat, R. I., P. Bartley, T. J. McLaughlin, R. D. Potter, R. E. Raymond, and W. L. Willis, 1998, Tank Waste Remediation System Retrieval and Disposal Mission Technical Baseline Summary Description, HNF-1901, Rev. 0, prepared by Lockheed Martin Hanford Corporation for Fluor Daniel Hanford, Inc., Richland, Washington.

RI, 1996, Project Hanford Management Contract (PHMC), DE-AC06-96RI13200, U.S. Department of Energy, Richland Operations Office, Richland, Washington. 
HNF-1882 Rev 0

\section{APPENDIX A}

\section{GUIDANCE AND REQUIREMENTS TO DELIVERABLES CROSSWALK}

TWRS Retrieval and Disposal Mission Infrastructure Plan 
HNF-1882 Rev 0

This page intentionally left blank. 
Table A-1. Guidance and Requirements to Deliverables Crosswalk - TWRS Retrieval and Disposal Mission Infrastructure Plan.

\begin{tabular}{|c|c|c|}
\hline Guidance or Requirement & Status & Implementing Location \\
\hline $\begin{array}{l}\text { I DOE Letter to H J Hatch, FDH, from W J J } \\
\text { Taylor, DOE dated Auguist } 8,1997,49757,62 \mathrm{~A}(36 \\
\text { ITEM CHECKI (ST) }\end{array}$ & $\sqrt{2+2}$ & (3) \\
\hline $\begin{array}{l}\text { 2. Requirements are identified, validated, and } \\
\text { documented. }\end{array}$ & $\mathrm{I}$ & Section 3.0 \\
\hline 3. Requirements are allocated to functions. & 1 & Section 3.0 \\
\hline $\begin{array}{l}\text { 8. Operations plans that describe how the PHMC } \\
\text { team will execute the tech baseline have been } \\
\text { prepared for all projects and are supported by lower- } \\
\text { tier plans. The operation plans are consistent with } \\
\text { MYWP and LCAM. Ops. and Maintenance. plans are } \\
\text { integrated. }\end{array}$ & 1 & Entire Document \\
\hline $\begin{array}{l}\text { 11. Waste feed plans and implementing actions and } \\
\text { procedures are on track. }\end{array}$ & I & Entire Document \\
\hline $\begin{array}{l}\text { 12. Infrastructure support plan and implementing } \\
\text { actions and procedures are on track. }\end{array}$ & $\mathrm{I}$ & Entire Document and TBRs \\
\hline 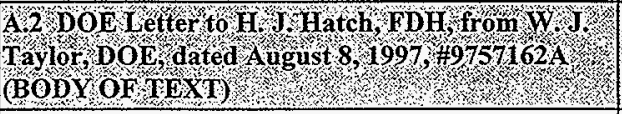 & & \\
\hline \multicolumn{3}{|l|}{$\begin{array}{l}\text { General PHMC Responsibilities from RL's 8/8/97 } \\
\text { letter, Section 2.1 }\end{array}$} \\
\hline 4. Work in the technical baseline can be performed & $\mathrm{I}$ & $\begin{array}{l}\text { Entire Document; Sections 3, 5, 6, } \\
\text { and } 7\end{array}$ \\
\hline \multicolumn{3}{|l|}{$\begin{array}{l}\text { Specific Responsibility from RL's August 8, } 1997 \\
\text { letter, Section } 2.2\end{array}$} \\
\hline $\begin{array}{l}\text { 2. Infrastructure support can be provided to the } \\
\text { private vendors as specified in the final privatization } \\
\text { contract and ICDs }\end{array}$ & I & $\begin{array}{l}\text { See references in document to MYWP } \\
\text { and Tech. Baseline Summary } \\
\text { Description, which references } \\
\text { Infrastructure CDRs; Sections 3, 5, 6, } \\
\text { and } 7\end{array}$ \\
\hline $\begin{array}{l}\text { A } 3 \text { DOE Letter H. Ha Heh, FDH, from William } \\
\text { J. Taylor, DOE, dated December } 2,1997, \# 9761291\end{array}$ & 3 & का \\
\hline $\begin{array}{l}\text { 5. Provide specific information to address the ten } \\
\text { areas in Paragraph } 4.2 .4 \text { of the August } 8 \mathrm{DOE} \text { letter of } \\
\text { direction }\end{array}$ & . & \\
\hline
\end{tabular}




\section{HNF-1882 Rev 0}

Table A-1. Guidance and Requirements to Deliverables Crosswalk - TWRS Retrieval and Disposal Mission Infrastructure Plan.

\begin{tabular}{|c|c|c|}
\hline Guidance or Requirement & Status & Implementing Location \\
\hline $\begin{array}{l}\text { j. Deliver to DOE or make available for DOE } \\
\text { review, Draft Program Plans }\end{array}$ & I & Entire document is available \\
\hline $\begin{array}{l}\text { 11. Make a Quality Assurance plan available for } \\
\text { DOE review in January. }\end{array}$ & · & $\begin{array}{l}\text { Quality Assurance Plans will be } \\
\text { prepared in March, } 1998 .\end{array}$ \\
\hline $\begin{array}{l}\text { e. Show how Quality Assurance will be implemented } \\
\text { in the infrastructure }\end{array}$ & $\mathrm{I}$ & Section 5.4 .1 \\
\hline C1 Interface Control Documents & 3. & W \\
\hline 1. Raw Water & I & $\begin{array}{l}\text { Section } 3 \text { references the Technical } \\
\text { Baseline Summary Description, which } \\
\text { references the ICD }\end{array}$ \\
\hline 2. Potable Water & I & $\begin{array}{l}\text { Section } 3 \text { references the Technical } \\
\text { Baseline Summary Description, which } \\
\text { references the ICD }\end{array}$ \\
\hline 9. Land for Siting & I & $\begin{array}{l}\text { Section } 3 \text { references the Technical } \\
\text { Baseline Summary Description, which } \\
\text { references the ICD }\end{array}$ \\
\hline 11. Electricity & I & $\begin{array}{l}\text { Section } 3 \text { references the Technical } \\
\text { Baseline Summary Description, which } \\
\text { references the ICD }\end{array}$ \\
\hline 12. Roads and Rails. & I & $\begin{array}{l}\text { Section } 3 \text { references the Technical } \\
\text { Baseline Summary Description, which } \\
\text { references the ICD }\end{array}$ \\
\hline $\begin{array}{l}\text { D } 1 \text { Detailed nstructions or Assessment of RTP } \\
\text { Sppendix C, Noyember } 14,1997\end{array}$ & trotions & 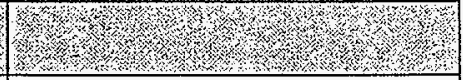 \\
\hline $\begin{array}{l}\text { 7. Show the ability of the PHMC Team to provide the } \\
\text { infrastructure necessary to handle all by-products of } \\
\text { the waste processing. }\end{array}$ & $\mathrm{I}$ & See references in Section $3,5,6$, and 7 \\
\hline $\begin{array}{l}\text { 8. Show the PHMC's ability to provide those } \\
\text { functions and carry out those responsibilities } \\
\text { described in the following ICDs: }\end{array}$ & & \\
\hline a. ICD-1 Raw Water & I & $\begin{array}{l}\text { See references in Section } 3,7.1,7.2, \\
7.3 \text { which lead the reader to the CDRs, } \\
\text { MYWP, Logic diagrams, Activity Data } \\
\text { Sheets }\end{array}$ \\
\hline b. ICD-2 Potable Water & I & $\begin{array}{l}\text { See references in Section } 3,7.1,7.2, \\
7.3 \text { which lead the reader to the CDRs, } \\
\text { MYWP, Logic diagrams, Activity Data } \\
\text { Sheets }\end{array}$ \\
\hline
\end{tabular}


Table A-1. Guidance and Requirements to Deliverables Crosswalk - TWRS Retrieval and Disposal Mission Infrastructure Plan.

\begin{tabular}{|c|c|c|}
\hline Guidance or Requirement & Status & Implementing Location \\
\hline c. ICD-5 Non-Rad Non-Dangerous Liquid Effluents & I & $\begin{array}{l}\text { See references in Section } 3,7.1,7.2, \\
7.3 \text { which lead the reader to the CDRs, } \\
\text { MYWP, Logic diagrams, Activity Data } \\
\text { Sheets }\end{array}$ \\
\hline d. ICD-6 Rad Dangerous Liquid Effluents & I & $\begin{array}{l}\text { See references in Section } 3,7.1,7.2, \\
7.3 \text { which lead the reader to the CDRs, } \\
\text { MYWP, Logic diagrams, Activity Data } \\
\text { Sheets }\end{array}$ \\
\hline e. ICD-9 Land & I & $\begin{array}{l}\text { See references in Section } 3,7.1,7.2 \text {, } \\
7.3 \text { which lead the reader to the CDRs, } \\
\text { MYWP, Logic diagrams, Activity Data } \\
\text { Sheets }\end{array}$ \\
\hline f. ICD-11 Electricity & I & $\begin{array}{l}\text { See references in Section } 3,7.1,7.2, \\
7.3 \text { which lead the reader to the CDRs, } \\
\text { MYWP, Logic diagrams, Activity Data } \\
\text { Sheets }\end{array}$ \\
\hline g. ICD-12 Roads/Rails & I & $\begin{array}{l}\text { See references in Section } 3,7.1,7.2, \\
7.3 \text { which lead the reader to the CDRs, } \\
\text { MYWP, Logic diagrams, Activity Data } \\
\text { Sheets }\end{array}$ \\
\hline $\begin{array}{l}\text { 9. Show the ability of the PHMC Team to turnover } \\
\text { waste feed tanks AP-106 and } 108 \text { to private. } \\
\text { contractors per ICD-21. }\end{array}$ & $I$ & $\begin{array}{l}\text { See references in Section } 3,7.1,7.2, \\
7.3 \text { which lead the reader to the CDRs, } \\
\text { MYWP, Logic diagrams, Activity Data } \\
\text { Sheets. }\end{array}$ \\
\hline $\begin{array}{l}\text { 12. Identify projects that directly support } \\
\text { infrastructure, based on project plans. }\end{array}$ & I & $\begin{array}{l}\text { See Section } 3 \text { references to the } \\
\text { Technical Baseline Summary } \\
\text { Description, which references CDRs } \\
\text { for Infrastructure projects }\end{array}$ \\
\hline $\begin{array}{l}\text { 24. Show an ability to support private contractors } \\
\text { regarding the infrastructure to receive by-products } \\
\text { through the PHMC Team's Quality Assurance } \\
\text { Program. }\end{array}$ & I & Sections $3,5.4 .1,7.1,7.2$, and 7.3 \\
\hline $\begin{array}{l}\text { D.3 Plan for Deternining PHMC-Team's RTP for } \\
\text { Waste Feed Delivery, Document Checklist (Table } \\
\text { (3) }\end{array}$ & & H. \\
\hline $\begin{array}{l}\text { 10. Plans include providing infrastructure necessary } \\
\text { for Phase } 1 \text { waste retrieval and transfer from SSTs. }\end{array}$ & I & Sections $3,7.1,7.2$, and 7.3 \\
\hline
\end{tabular}


Table A-1. Guidance and Requirements to Deliverables Crosswalk - TWRS Retrieval and Disposal Mission Infrastructure Plan.

\begin{tabular}{|c|c|c|}
\hline Guidance or Requirement & Status & Implementing Location \\
\hline $\begin{array}{l}\text { 53. Plans define equipment requirements, } \\
\text { infrastructure requirements, and recommend a } \\
\text { preferred alternative consistent with DOE guidance. }\end{array}$ & $I$ & Sections $3,7.1,7.2$, and 7.3 \\
\hline $\begin{array}{l}\text { D s praft plan for Deternining pqp for } \\
\text { Infrastructure \& Byproducts Delivery }\end{array}$ & Y.t. & 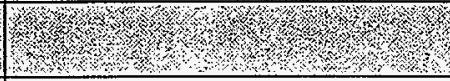 \\
\hline $\begin{array}{l}\text { 1. Show the ability to provide infrastructure at the } \\
\text { correct rate to the correct location. }\end{array}$ & 1 & $\begin{array}{l}\text { The conceptual design reports and the } \\
\text { P3 schedule identify the scope and } \\
\text { plan to complete infrastructure Draft } \\
\text { MOA's with DYN and WMH identify } \\
\text { the linkage and scope with the } \\
\text { operations }\end{array}$ \\
\hline $\begin{array}{l}\text { 8. Show that correct procedures and policies have } \\
\text { been established at the Program level and passed } \\
\text { down to the Project level. }\end{array}$ & $\mathrm{I}$ & Entire Document \\
\hline 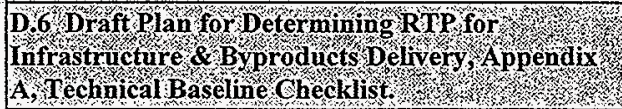 & (2) & 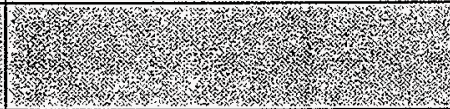 \\
\hline $\begin{array}{l}\text { 11. Provide evidence of independent review planning } \\
\text { for Infrastructure Project (systems, technical, design, } \\
\text { definitive design, ORR). (2.3.1-2.3.7) }\end{array}$ & 1 & $\begin{array}{l}\text { Evidence is implicit in W- } 519 \text { being a } \\
\text { validated project. See references in } \\
\text { Section 3. Evidence is found in CDRs } \\
\text { which are referenced by the Technical } \\
\text { Baseline Summary Description (which } \\
\text { is referenced in Section 3). }\end{array}$ \\
\hline $\begin{array}{l}\text { 18. Provide for infrastructure control systems to } \\
\text { ensure safe construction, ops and maintenance. (4.1.5- } \\
\text { 4.1.8) }\end{array}$ & I & $\begin{array}{l}\text { Sections } 5 \text { and } 6 \text { identify those } \\
\text { organizations that have procedures and } \\
\text { control systems. }\end{array}$ \\
\hline $\begin{array}{l}\text { 21. Show INTERFACE description. in ICDs, MOUs, } \\
\text { funding, engineering, document sign-off, w/Safety, } \\
\text { Emergency., Maintenance, LMHC internal, } \\
\text { construction. coordination, DOE interface, and } \\
\text { configuration control of MYWP/ICDs has been } \\
\text { covered. (5.1.1.-5.1.15; 5.2.1-5.2.6) }\end{array}$ & 1 & Sections $3,5,6$, and 7 \\
\hline $\begin{array}{l}\text { D. } \mathrm{D} \text { Praft Plan for Deternining RT } \mathrm{P} \text { or } \\
\text { nfrastructure \& Byproducts Delivery, Appendix } \\
\mathrm{B}, \text { Programmatic Baseline Checklist. }\end{array}$ & & 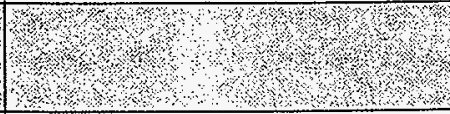 \\
\hline $\begin{array}{l}\text { 28. Indicate that all activities on logic diagrams are } \\
\text { tiered from contractual or MAR requirements. (1.1.1) }\end{array}$ & $\mathrm{I}$ & Section 3.0 \\
\hline
\end{tabular}


Table A-1. Guidance and Requirements to Deliverables Crosswalk - TWRS Retrieval and Disposal Mission Infrastructure Plan.

\begin{tabular}{|c|c|c|}
\hline Guidance or Requirement & Status & Implementing Location \\
\hline $\begin{array}{l}\text { 30. Indicate that the Infrastructure Level-1 Logic is } \\
\text { consistent with the CDR schedules, the feed delivery } \\
\text { schedules, the Privatization Contractor's schedules, } \\
\text { and other appropriate interface schedules. (2.1.1- } \\
\text { 2.1.3) }\end{array}$ & I & Section 7.2 \\
\hline $\begin{array}{l}\text { 31. If an Operations Plan is needed and exists, } \\
\text { indicate that it is infrastructure- need-specific, } \\
\text { consistent with LCAM and MYWP. }(2.2 .2-2.2 .4)\end{array}$ & I & $\begin{array}{l}\text { An operation plan will be developed } \\
\text { over the next two years. It will be } \\
\text { infrastructure- need-specific, consistent } \\
\text { with LCAM and MYWP. (2.2.2-2.2.4) } \\
\end{array}$ \\
\hline $\begin{array}{l}\text { 32. Indicate that the WBS is accurate and consistent } \\
\text { with the MYWP. }(2.3 .1-2.3 .2)\end{array}$ & I & Section 7.1 \\
\hline 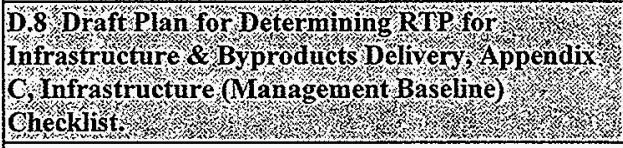 & 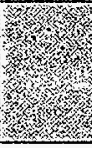 & 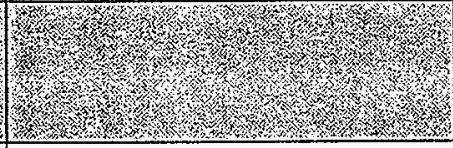 \\
\hline $\begin{array}{l}\text { 39. Indicate that adequate reports of schedule, cost, } \\
\text { cost variances, project status, DOE requirements, } \\
\text { problem resolution, and task tracking by WBS are in } \\
\text { place and timely. (1.1.1-1.1.8;1.1.10-1.1.11) }\end{array}$ & I & Section 6.0 \\
\hline $\begin{array}{l}\text { 44. Provide Acquisition Plan or Procurement Plan } \\
\text { which contains vendor prequalification and } \\
\text { testing/verification and which provide procurement } \\
\text { event-sequence leading to project completion.on time. } \\
\text { (1.2.9) }\end{array}$ & I & $\begin{array}{l}\text { To be developed in FY 98; See Section } \\
5.4 .3\end{array}$ \\
\hline $\begin{array}{l}\text { 46. Confirm that if USQs exist, strategy for resolving } \\
\text { them is in the baselines, and strategy to implement } \\
\text { Safety Authorization. Bases to get to hot start are in } \\
\text { place. (1.3.3) }\end{array}$ & I & $\begin{array}{l}\text { The strategy is part of TWRS. See } \\
\text { procedures referenced in Sections } 5.4 .2 \\
\text { and } 6.0 \text { and see TWRS operational } \\
\text { support procedures }\end{array}$ \\
\hline $\begin{array}{l}\text { 50. Show that the training program is acceptable or is } \\
\text { not needed. (1.6.1) }\end{array}$ & I & $\begin{array}{l}\text { Training program will be developed in } \\
\text { FY } 98 \text { and FY } 99 \text {. See Sections } 2.2 \\
\text { and 5.4.3. }\end{array}$ \\
\hline 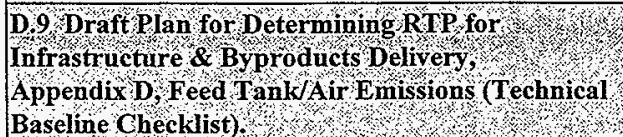 & & W \\
\hline
\end{tabular}


Table A-1. Guidance and Requirements to Deliverables Crosswalk - TWRS Retrieval and Disposal Mission Infrastructure Plan.

\begin{tabular}{|c|c|c|}
\hline Guidance or Requirement & Status & Implementing Location \\
\hline $\begin{array}{l}\text { 54. Provide (on request) an Infrastructure SEMP } \\
\text { based on the TWRS SEMP. (2.2.1) }\end{array}$ & I & $\begin{array}{l}\text { Acknowledges that the appropriate } \\
\text { system engineering documents will be } \\
\text { prepared. The TBR identifies an } \\
\text { infrastructure SEMP as on of the } \\
\text { documents to be prepared }\end{array}$ \\
\hline $\begin{array}{l}\text { E1 TWRS Waste Disposal Division Planning } \\
\text { Guidance dated July } 7,1997 \text { (Updated December } \\
12,1997)\end{array}$ & (2) & W. \\
\hline $\begin{array}{l}\text { Division will prepare integrated plans consistent with } \\
\text { the technical baseline and fully coordinated across } \\
\text { projects. }\end{array}$ & $I$ & Sections 5,6 , and 7 \\
\hline $\begin{array}{l}\text { Private contractor(s) will perform retrieval for Phase } 2 \\
\text { (show in plans, schedule, budget). }\end{array}$ & I & \\
\hline $\begin{array}{l}\text { Infrastructure will support new or modified physical } \\
\text { interfaces with the privatization contractors. }\end{array}$ & $\mathrm{I}$ & Section 4.0 \\
\hline $\begin{array}{l}\text { Infrastructure will ensure all needs identified by the } \\
\text { private contractors and agreed to by DOE are } \\
\text { satisfied. }\end{array}$ & I & $\begin{array}{l}\text { Infrastructure will meet all needs } \\
\text { agreed upon. }\end{array}$ \\
\hline $\begin{array}{l}\text { Infrastructure will manage the construction of the } 6 \\
\text { elements listed in paragraph } 3.3 .3 .3 \text {, and provide and } \\
\text { maintain utilities and serves as agreed to with the } \\
\text { private contractor. }\end{array}$ & 1 & Sections 2.2 and 3.0 \\
\hline $\begin{array}{l}\text { Decontaminate and decommission all infrastructure } \\
\text { that provided services to the PC's and deactivate } \\
\text { systems following D\&D of the facilities. }\end{array}$ & I & $\begin{array}{l}\text { To be planned during Phase } 1 \mathrm{~B} \text {; See } \\
\text { Executive Summary and Section } 4.0\end{array}$ \\
\hline
\end{tabular}




\section{DISTRIBUTION SHEET}

\begin{tabular}{|c|c|c|c|c|c|}
\hline \multirow{2}{*}{$\begin{array}{l}\text { To } \\
\text { Document Control Services }\end{array}$} & \multirow{2}{*}{\multicolumn{3}{|c|}{$\begin{array}{l}\text { From } \\
\text { Tank Waste Remediation System }\end{array}$}} & \multicolumn{2}{|l|}{ Page 1 of 1} \\
\hline & & & & \multicolumn{2}{|c|}{ Date January 3, 1998} \\
\hline \multirow{2}{*}{\multicolumn{4}{|c|}{$\begin{array}{l}\text { Project Title/Work Order } \\
\text { Tank Waste Remediation System (HNF-1882) }\end{array}$}} & \multirow{2}{*}{\multicolumn{2}{|c|}{$\begin{array}{l}\text { EDT No. } \quad 622840 \\
\text { ECN NO }\end{array}$}} \\
\hline & & & & & \\
\hline Name & MSIN & $\begin{array}{c}\text { Text } \\
\text { With All } \\
\text { Attach. }\end{array}$ & $\begin{array}{l}\text { Text } \\
\text { OnTy }\end{array}$ & $\begin{array}{l}\text { Attach./ } \\
\text { Appendix } \\
\text { Only }\end{array}$ & $\begin{array}{l}\text { EDT/ECN } \\
\text { Only }\end{array}$ \\
\hline
\end{tabular}

J.N. A7ibert

J.H. Baldwin

M.P. Delozier

0. A. Halvorson

D.M. Hammond

J.P. Harris, III

J.0. Honeyman

K.N. Jordan

R.A. Kirkbride

R.J. Murkowski

R.J. Parazin

M.A. Payne

R.W. Powe1 1

R.E, Raymond

S.H. Rifaey

B. Root

P.S. Schaus

R. L. Treat

J.M. Vann

R.D. Wojtasek
S2-48 $\quad x$

H5-03 $x$

R2-58 $X$

G3-21 $X$

R1-44 $X$

R1-49 $x$

G3-21 $X$

G3-21 $X$

H5-27 $X$

H6-37 $x$

H5-49 $X$

R2-58 $\quad x$

H5- 03 - $X$

R2-38 $x$

R1-56 $X$

G3-21 3 copies

H5-03 $X$

H5- $03 \quad X$

H6-37 $\quad X$

G3-21 $X$

\section{Central Files}

B1-07 $x$

